THE OHIO STATE UNIVERSITY

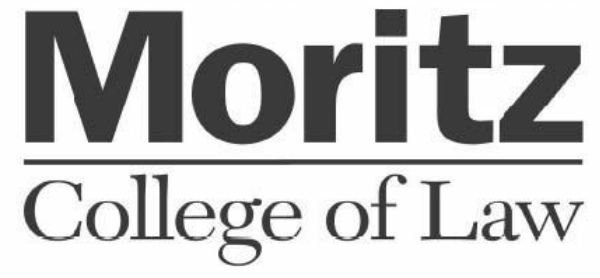

\title{
In NLRB Recess Appointments Case, Roberts Court Can Now Show It Knows How to Exercise Judicial Restraint
}

\author{
Peter M. Shane \\ Public Law and Legal Theory Working \\ Paper Series \\ No. 221
}

July 29, 2013

This working paper series is co-sponsored by the Center for Interdisciplinary Law and Policy Studies at the Moritz College of Law

This paper can be downloaded without charge from the Social Science Research Network Electronic Paper Collection: http://ssrn.com/abstract=2304256 
Reproduced with permission from Daily Report for Executives, 145 DER B-1, 07/29/2013. Copyright $\odot 2013$ by The

Bureau of National Affairs, Inc. (800-372-1033) http://www.bna.com

\section{Government Operations}

If the Senate soon confirms a full complement of members for the National Labor Relations Board, the Obama administration should ask the Supreme Court in Noel Canning $v$. NLRB to remand the case, without decision, to be re-heard by the NLRB, author Prof. Peter Shane of Ohio State Law school writes. The court should grant the request, showing a judicial restraint for which the Roberts bench is not known-and returning the recess appointments controversy to the elected branches of government, where it belongs.

\section{In NLRB Recess Appointments Case, Roberts Court Can Now Show It Knows How to Exercise Judicial Restraint}

\section{Peter M. Shane}

$\mathrm{f}$ the Senate soon confirms a full complement of members for the National Labor Relations Board, the Obama administration will have a unique opportunity. It should ask the Supreme Court in Noel Canning $v$. NLRB ${ }^{1}$ - the recess appointments case out of the D.C. Circuit-to exercise a virtue rarely associated with the Roberts Court, namely, judicial restraint. It can request that the Court remand the case, without decision, to the NLRB to be re-heard. Because the members then in place will all hold office under fully confirmed appointments, any decision they render will be free of constitutional infirmity. The Supreme Court will be positioned to leave the recess appointments controversy where it belongs-to the elected branches of government.

The mere confirmation and appointment of the new NLRB members would likely not be enough to render

${ }^{1} 705$ F.3d 490 (D.C. Cir. 2013). The court held that President Obama's recess appointments of three members to the National Labor Relations Board were invalid because the recess appointments power only applies during an intersession recess of the Senate, not during intrasession adjournment.

Peter M. Shane is the Jacob E. Davis and Jacob E. Davis II Chair in Law at Ohio State University's Moritz College of Law. The opinions expressed are those of the author.
Noel Canning moot. That is because, as former Justice Department attorney John Elwood has pointed out, ${ }^{2}$ the NLRB actually loses jurisdiction-that is, its power to decide a case-once the record in that case is formally transferred to the courts.

The NLRB can take the case back only if the Court remands the case, thus returning the record, which is exactly what the Solicitor General should ask the Court to do.

Rehearing Would Be Speedy. Upon receiving the record, the NLRB could not simply stamp it, "Reaffirmed." The Board would have to "re-hear" the case. Under the Administrative Procedure Act (APA), ${ }^{3}$ however, it would not have to start from scratch. It could propose to the parties that the Board take what the statute calls "official notice" of the entire earlier record ${ }^{4}$ and decide the case on the basis of that record, unless the parties wish to contribute anything new.

At this point, of course, Noel Canning might simply abandon its appeal. Why? Because prior to reaching its constitutional analysis of recess appointments, the D.C. Circuit found that the earlier NLRB decision against Noel Canning met the requisite legal standards under the National Labor Relations Act and the APA. Noel

\footnotetext{
2 John Elwood, Could Senate Action After Cloture Reform Moot Noel Canning?, The Volokh Conspiracy (July 12, 2013), available at http://www.volokh.com/2013/07/12/could-senateaction-after-cloture-reform-moot-noel-canning/.

${ }^{3} 5$ U.S.C. $\$ \S 551$, et seq.

${ }^{4} 5$ U.S.C. \& $556(\mathrm{e})$.
} 
Canning and its lawyers will surely recognize the probability that the earlier NLRB decision will be reaffirmed both by the Board and the courts. They and the Board will realize that the record that once satisfied the D.C. Circuit on the non-constitutional issues would likely do so again.

\section{The Noel Canning court found that the earlier}

\section{NLRB decision against Noel Canning met the}

\section{requisite legal standards under the National Labor}

\section{Relations Act and the APA.}

The NLRB could likewise offer to make the same procedure available to anyone whose cases between 2010 and 2013 were decided, in part, by intrasession-recessappointed Board members, effectively precluding further constitutional controversy. The Justice Department should ask the Third and Fourth Circuits to return their recent recess appointments cases, ${ }^{5}$ as well, to the Board so that the parties, should they choose, can take advantage of the rehearing procedure.

Following this course of action would enable the Court to exercise a bit of self-discipline frequently discussed, but too seldom followed: avoiding the unnecessary resolution of constitutional issues. Courts exercise this judicial virtue, when they do, because they realize that constitutional rulings have a sometimes unfortunate "freezing" effect on government. That is, if the courts misinterpret a federal statute, Congress, in theory, can always amend the statute to articulate its purposes more clearly. Once the courts rule a government practice unconstitutional, however, the issue leaves the legislative arena. A Supreme Court constitutional mistake can be cured only by a different Supreme Court majority or by a constitutional amendment.

In deciding their respective recess appointments cases, the D.C. and Fourth Circuits paid at least partial homage to this principle. That is because both courts, before deciding on the constitutionality of intrasession recess appointments, appropriately inquired first into whether the challenged NLRB orders might be set aside because they violated applicable statutes. (The Third Circuit inexplicably omitted this step.) Each court concluded that the orders under review were entirely lawful-except for the contested recess appointments. Had fully confirmed NLRB members rendered the exact same decisions for the exact same reasons, the orders would have been upheld. If the courts had not so decided, they would have never discussed the constitutionality of the recess appointments.

The Virtues of Judicial Restraint. There are two important additional reasons in the NLRB cases for the Solicitor General to invite, and for the courts to exhibit, judi-

\footnotetext{
${ }^{5}$ NLRB v. New Vista Nursing and Rehabilitation, - - F.3d — 2013 WL 2099742 (3d Cir. 2013); NLRB v. Enterprise Leasing Company Southeast, LLC, - F.3d —, 2013 WL 3722388 (4th Cir. 2013). Both decisions held intrasession recess appointments constitutionally invalid.
}

cial restraint. The first is the risk of exacerbating an already increased public perception of partisan judging.

As it happens, three U.S. Courts of Appeals-in the Third, Fourth, and D.C. Circuits-have now rendered opinions invalidating NLRB decisions on the ground that the Board's quorum included one or more members appointed by President Obama during an intrasession recess of the Senate. (These decisions conflict with a 2004 Eleventh Circuit case upholding the constitutionality of intrasession appointments. ${ }^{6}$ ) Unfortunately, although the recent pattern may reflect what statisticians would call a "small numbers problem," it also happens that the seven judges on the three panels who voted to reject the Obama appointees were all appointed by Republican presidents. President Obama appointed the two dissenters.

Should the Supreme Court finally overturn the Obama appointments, it would inevitably feed the appearance of judicial partisanship. There should be little incentive to run this risk when the issue presented-the constitutionality of intrasession recess appointments-is an issue on which, over the long term, it is impossible to predict which party has more at stake.

\section{The seven judges on the three panels who voted to reject the Obama appointees were all appointed by Republican presidents.}

The second, arguably even more important, reason for judicial restraint is that any final constitutional judgment on intrasession appointments could have a profound impact on the dynamics of the entire appointments process, especially during periods of divided government. In granting certiorari in Noel Canning $v$. NLRB, the Supreme Court agreed to address three questions:

- Whether the president's recess appointment power under Article II of the Constitution may be exercised during a recess that occurs within a session of the Senate, or is instead limited to recesses that occur between sessions;

- Whether the president's recess appointment power may be exercised to fill vacancies that exist during a recess, or is instead limited to vacancies that first arose during that recess; and

- Whether the president's recess appointment power may be exercised when the Senate is convening every three days in pro forma sessions. ${ }^{7}$

Justices Could Kill Recess Appointments. Depending on the Court's rationale, rulings favoring the plaintiff could effectively end recess appointments or prompt presidents to engage in yet more creative and provocative

\footnotetext{
${ }^{6}$ Evans v. Stephens, 387 F.3d 1220 (11th Cir. 2004). In Evans, three Democratic appointees joined with five Republican appointees en banc in upholding a George W. Bush intrasession recess appointment, with two Democratic appointees in dissent.

${ }^{7}$-- S.Ct. —, 2013 WL 1774240 (2013).
} 
end-runs around the Senate. (Astonishingly, the Fourth Circuit majority regarded the availability of yet more confrontational presidential tactics as an argument why its ruling would work no harm to the executive branch. ${ }^{8}$ ) Rulings favoring the NLRB might prompt presidents to use intrasession recess appointments more aggressively once the cloud of constitutional doubt has been lifted. ${ }^{9}$

Even if the Court declined a Solicitor General request to remand Noel Canning to the NLRB immediately, the Court would still have another path of judicial restraint it could and should follow. It could decide that the key issues presented regarding the interpretation of the recess appointments power are so-called "political questions" - that is, questions that the Court regards as constitutionally left to the elected branches of government to decide for themselves.

The most closely analogous case is probably Goldwater $v$. Carter ${ }^{10}$ a 1979 case in which the Supreme Court declined to determine whether President Carter acted within his constitutional authority in terminating the U.S. mutual defense treaty with Taiwan or whether the treaty termination power is a power that presidents share with either the Senate alone or with both Houses of Congress. Writing for a Court plurality, thenAssociate Justice Rehnquist characterized the controversy as "a nonjusticiable political dispute that should be left for resolution by the Executive and Legislative Branches of the Government." "11 Justice Powell would have dodged the issue by finding the case not yet ripe for judicial resolution, yet his opinion was motivated by much the same considerations as Rehnquist's: "Differences between the President and the Congress," Powell observed, "are commonplace under our system." $12 \mathrm{He}$ continued: "The differences should, and almost invariably do, turn on political rather than legal considerations. The Judicial Branch should not decide issues affecting the allocation of power between the President and Congress until the political branches reach a constitutional impasse." 13

The Court in Goldwater v. Carter was undoubtedly influenced by the dispute's implications for foreign affairs and the judiciary's traditional reluctance to narrow the president's options in that arena. But the treaty termination dispute and the recess appointments dispute resemble each other in two respects that are more significant.

${ }^{8}$ NLRB v. Enterprise Leasing Company Southeast, LLC, No. 12-1514, slip op. at 118 (4th Cir., July 17, 2013) (suggesting that the President, if the two Houses of Congress refused to agree on a date to adjourn, could exercise his Article II power to force them into adjournment in order to create a recess; no President has ever exercised this authority).

${ }^{9}$ It is worth noting that President Obama is the least aggressive user in recent decades of the intrasession recess appointments power, having made only 32 such designations during his first term of office. (George W. Bush was the most active intrasession appointer, having made 141 such appointments over eight years.) Henry Hogue, et al., The Noel Canning Decision and Recess Appointments Made from 19812013, at 4 (CRS Feb. 4, 2013) (tabulating presidential recess appointments since 1981).

10444 U.S. 996 (1979).

${ }^{11}$ Id., at 1003 (Rehnquist, J., concurring in the judgment).

${ }_{12}$ Id., at 997 (Powell, J., concurring).

${ }^{13} \mathrm{Id}$.
First, unlike separation of powers cases that the Court has resolved-cases like Youngstown Steel, ${ }^{14}$ Chadha, ${ }^{15}$ or Boumediene ${ }^{16}$-Noel Canning presents no issue with any direct connection to individual rights or liberties. That is, there is no reason to think that the fact of recess appointment during a Senate session, as opposed to between Senate sessions, gives a private party before the NLRB a hearing that is any less fair, robust, or respectful of the law. Life, liberty and property are simply not at issue.

\section{Courts should avoid "a dispute between coequal}

branches of our Government, each of which has

resources available to protect and assert its

\author{
interests." \\ Justice Rhenquist, GoldWater v. CARTER
}

Moreover, in both cases, the Court is confronted with "a dispute between coequal branches of our Government, each of which has resources available to protect and assert its interests, resources not available to private litigants outside the judicial forum." ${ }^{17}$ Where Congress assigns to the elected branches a shared power, as with treaties or appointments, the Court behaves wisely in allowing each branch's political and institutional incentives and disincentives to operate, as they were intended, to curb overreach by the other branch.

Of course, for the Court to denominate a legal issue as a "political question" is itself to engage in a debatable matter of constitutional interpretation, which, if the Senate proceeds as anticipated, will be wholly unnecessary.

A Supreme Court that has deregulated corporate campaign spending, judicialized the Second Amendment, overturned both the Voting Rights and Defense of Marriage Acts, and cut from whole cloth pretty much every important holding in its resolution of the Obamacare challenges may be all too eager to play constitutional referee on recess appointments. As in the case of the treaty termination dispute, there is text in the Constitution available for the Court to interpret. I believe the Noel Canning Court interpreted that text incorrectly. ${ }^{18}$ That does not mean the Court should resolve

\footnotetext{
${ }^{14}$ Youngstown Sheet \& Tube Co. v. Sawyer, 343 U.S. 579 (1952) (overturning President Truman's seizure of steel mills as beyond the scope of unilateral presidential authority).

15 I.N.S. v. Chadha, 462 U.S. 919 (1983) (invalidating Congress's exercise of a one-House legislative veto as a violation of the Constitution's Presentment Clauses and bicameralism requirement).

${ }^{16}$ Boumediene v. Bush, 553 U.S. 723 (2008) (holding Congress without authority to suspend habeas corpus for alleged enemy combatants held in custody at Guantanamo).

17 Goldwater v. Carter, 444 U.S. 996, 1004 (1979) (Rehnquist, J., concurring in the judgment).

${ }^{18}$ For my (critical) analyses of Noel Canning and NLRB $v$. New Vista Nursing and Rehabilitation, the Third Circuit case, see Peter M. Shane, The Future of Recess Appointments in Light of Noel Canning v. NLRB, Bloomberg BNA Daily Report for Executives B1-B5 (May 14, 2013), available at http:// about.bloomberglaw.com/practitioner-contributions/the-
} 
the matter. The Solicitor General can help the Court

future-of-recess-appointments-in-light-of-noel-canning-v-nlrb/, and NLRB v. New Vista Nursing and Rehabilitation: The Third Circuit Further Fuels the Constitutional Conflict Over Recess Appointments, Bloomberg BNA Daily Report for Executives B1-B5 (May 24, 2013). steer a responsible path by asking it to return Noel Canning to the NLRB. 